\title{
OGÓLNOPOLSKA KONFERENCJA NAUKOWA „POLSKA 2015 - STAN REALIZACJI ZOBOWIĄZAŃ W ZAKRESIE OCHRONY PRAW CZLOWIEKA"
}

\author{
Poznań, 16 listopada 2015 r.
}

\begin{abstract}
VII Doroczna Konferencja Poznańskiego Centrum Praw Człowieka INP PAN, której współorganizatorem był Wydział Prawa i Administracji Uniwersytetu im. Adama Mickiewicza w Poznaniu, odbyła się 16 listopada 2015 r. Tematem konferencji był aktualny stan realizacji przez Polskę jej zobowiązań w zakresie ochrony praw człowieka wynikających z przynależności do międzynarodowego oraz europejskiego systemu ich ochrony.

Pierwszy panel poświęcony został zaległościom ratyfikacyjnym Polski w obszarze traktatów ochrony praw człowieka. Problem ten dostrzegany jest przez środowisko naukowe, organizacje pozarządowe, a także Rzecznika Praw Obywatelskich. Dr Anna Śledzińska-Simon w swoim referacie przedstawiła zaległości dotyczące przepisów antydyskryminacyjnych. Podkreśliła, że równie istotny wpływ na ochronę praw człowieka mają zaległości implementacyjne traktatów już ratyfikowanych. W referacie dr. Marcina Wujczyka na temat zaległości w obszarze praw socjalnych szczególna uwaga została poświęcona Zrewidowanej europejskiej karcie społecznej z 1996 r., która do tej pory nie została ratyfikowana przez Polskę. Dr Agata Wnukiewicz-Kozłowska przedstawiła natomiast wnikliwą analizę argumentów, które pojawiły się w dyskusji na temat ratyfikacji Konwencji Rady Europy o prawach człowieka i biomedycynie, konfrontując je z poszczególnymi postanowieniami Konwencji.
\end{abstract}

Polska, jako podlegająca jurysdykcji Europejskiego Trybunału Praw Człowieka, zobowiązana jest do wykonywania wyroków Trybunału zapadłych w sprawach przeciwko Polsce. Tej problematyce poświęcona została druga część konferencji. Ogólne uwagi na ten temat uwzględniające statystyki wykonywania wyroków i działalność podmiotów zaangażowanych w ten proces przedstawiła Justyna Chrzanowska pełniąca funkcję Pełnomocnika Ministra Spraw Zagranicznych ds. Postępowań przed Europejskim Trybunałem Praw Człowieka. Kolejny referat wygłoszony przez Jakuba Jaraczewskiego dotyczył realizacji postanowień dwóch wyroków wydanych w 2014 r.: Al-Nashiri i Abu-Zubayda przeciwko Polsce. Skarżący w tych sprawach byli przetrzymywani i poddawani torturom w tajnym więzieniu CIA, które znajdowało się na terytorium Polski. Prelegent podzielił się ze słuchaczami aktualnymi informacjami na temat stanu wykonania tego wyroku, poruszając m.in. interesującą kwestię wypłat odszkodowań dla skarżących. W przypadku jednego z nich doszło bowiem do kolizji przepisów prawa międzynarodowego, co spowodowało przekazanie środków do depozytu sądowego.

Tematyka kolejnego panelu związana była z przynależnością Polski do międzynarodowego systemu ochrony praw człowieka utworzonego w ramach Organizacji Narodów Zjednoczonych. W systemie tym ważną rolę pełnią zarówno organy traktatowe - komitety monitorujące przestrzeganie określonych traktatów praw człowieka, jak i mechanizmy Rady Praw Człowieka. Obie te struktury były przedmiotem wystapień tej części konferencji. Dr Katarzyna Sękowska-Kozłowska porównała uchwały kilku organów traktatowych wyrażajacych ocenę realizacji przez Polskę obowiązków wynikających z regulacji antydyskryminacyjnych. Rekomendacje skierowane do Polski przez Komitet Praw Dziecka były natomiast przedmiotem referatu dr Anny Natalii Schulz. Sprawozdanie Polski z implementacji Konwencji o prawach dziecka było rozpatrywane przez Komitet we wrześniu 2015 r. Prelegentka skomentowała m.in. rekomendację Komitetu dotyczaca tzw. okien życia, która wzbudziła zainteresowanie mediów i duże kontrowersje. Ocenie Polski w ramach mechanizmów Rady Praw Człowieka poświęcone były wystapienia dr Aleksandry Gliszczyńskiej-Grabias oraz Anny Połczyńskiej. Pierwsze z nich dotyczyło Powszechnego Przeglądu Okresowego, drugie - specjalnych sprawozdawców Rady Praw Człowieka. W ramach obu tych mechanizmów Polska nie jest poddawana rażącej krytyce, dostrzegane są jednak pewne problemy związane np. z ochroną praw reprodukcyjnych.

Ostatni panel poświęcony był kwestiom natury politycznej. Dr Agata Bieńczyk-Missala podsumowała działania Polski na rzecz wspierania demokracji i praw człowieka na świecie, wskazując, że w ostatnich latach zmniejszyła się aktywność naszego kraju na tym polu. Polityki zagranicznej 
dotyczyło również wystapienie Dominiki Bychawskiej-Siniarskiej, która bardzo krytycznie oceniła działanie Partnerstwa Wschodniego w obszarze ochrony praw człowieka. Prelegentka zwróciła szczególną uwagę na wpływ interesów gospodarczych na stosunek do członków Partnerstwa, podając jako przykład drastyczne różnice w traktowaniu kwestii praw człowieka i standardów demokratycznych w odniesieniu do Azerbejdżanu i Białorusi.

Wszystkim częściom konferencji towarzyszyła ożywiona dyskusja prowadzona przez jej moderatorów - profesorów Hannę Suchocka, Romana Wieruszewskiego, Jana Sandorskiego i Zdzisława Kędzię. Prelegenci mieli możliwość odpowiedzieć na liczne pytania zgromadzonych słuchaczy, którzy chętnie dzielili się swoimi spostrzeżeniami na temat omawianych problemów. Wśród uczestników konferencji znaleźli się nie tylko przedstawiciele środowiska akademickiego, ale także organizacji pozarządowych, policji, zawodów prawniczych oraz rządu.

Tegoroczna konferencja Poznańskiego Centrum Praw Człowieka INP PAN pozwoliła na wieloaspektowe podsumowanie aktualnego stanu realizacji zobowiązań prawnoczłowieczych w Polsce. Zaprezentowane referaty wykazały pozytywne i negatywne elementy tego stanu. Podjęto również próby określenia możliwych kierunków rozwoju ochrony praw człowieka w Polsce, jednocześnie podkreślając, jak istotne dla jej wzmacniania jest istnienie odpowiedniej woli politycznej wśród rządzących. Należy wyrazić nadzieję, że kolejne lata nie przyniosą regresu w realizacji zobowiązań w zakresie praw człowieka w Polsce, a wręcz przeciwnie - stan tej realizacji będzie się systematycznie poprawiał.

Anna Połczyńska

\title{
VII ZJAZD MŁODYCH TEORETYKÓW I FILOZOFÓW PRAWA „WYMIARY PRAWA"
}

\author{
Poznań, 6-9 września 2015 r.
}

Wydział Prawa i Administracji Uniwersytetu im. Adama Mickiewicza w Poznaniu od 6 do 9 września 2015 r. gościł uczestników VII Zjazdu Młodych Teoretyków i Filozofów Prawa „Wymiary prawa". Zjazd zorganizowany został przez prof. Marka Smolaka oraz jego współpracowników z Katedry Teorii i Filozofii Prawa WPiA UAM. Nieocenioną pomoc w przygotowaniu konferencji udzieliła Fundacja im. Profesora Zygmunta Ziembińskiego, jak również Koło Naukowe Teorii i Filozofii Prawa WPiA UAM. Już na wstępie należy zauważyć, że Zjazd Młodych Teoretyków i Filozofów Prawa stanowi wyjątkowy przykład, nie tylko w skali krajowej, ale i światowej, spotkań naukowych młodych adeptów nauki prawa, którzy we własnym gronie omawiaja zagadnienia istotne i ważkie dla młodego pokolenia teoretyków i filozofów prawa. Warto także podkreślić, że w zjeździe uczestniczyła imponująca liczba sześćdziesięciu młodych teoretyków, filozofów, socjologów oraz metodologów prawa z różnych ośrodków akademickich z całego kraju. Osią dyskusji Zjazdu uczyniono szeroko rozumiane wymiary prawa. Problematyka ta ogniskuje wiele bardzo interesujących zagadnień związanych z różnymi kontekstami prawa (w szczególności z jego kontekstem społecznym, językowym, politycznym, aksjologicznym czy kulturowym). Wymiary prawa dotyczą również poziomów refleksji nad prawem oraz wielu zagadnień metateoretycznych związanych ze sposobami badania prawa. Temat konferencji obejmował ponadto zagadnienie procesu stosowania prawa, jak i relacji zachodzących pomiędzy prawem a innymi systemami normatywnymi obowiązującymi w ramach społeczeństwa.

VII Zjazd Młodych Teoretyków i Filozofów Prawa otworzył uroczyście Dziekan WPiA UAM prof. dr hab. Roman Budzinowski, który powitał uczestników konferencji. Następnie swoje przemówienie wygłosił Kierownik Katedry Teorii i Filozofii Prawa WPiA UAM prof. dr hab. Marek Smolak, który podziękował wszystkim uczestnikom Zjazdu za przybycie i życzył im udanych obrad oraz dyskusji. Uczestników Zjazdu przywitała również prof. dr hab. Sławomira Wronkowska, która życzyła uczestnikom konferencji wartościowych debat.

Po otwarciu konferencji oraz mowach powitalnych rozpoczęła się inauguracyjna sesja plenarna, w której swoje referaty przedstawili: dr hab. Jadwiga Potrzeszcz z Katolickiego Uniwersytetu 